\title{
RESTORED LAYERS: RECONSTRUCTION OF HISTORICAL SITES AND RESTORATION OF ARCHITECTURAL HERITAGE: THE EXPERIENCE OF THE UNITED STATES AND RUSSIA (CASE STUDY OF ST. PETERSBURG)
}

\author{
Olga Pastukh*, Timothy Gray², Svetlana Golovina \\ ${ }^{1}$ Saint Petersburg State University of Architecture and Civil Engineering \\ Vtoraja Krasnoarmeyskaya st., 4, Saint Petersburg, Russia \\ ${ }^{2}$ Ball State University \\ Muncie, USA, Indiana
}

*Corresponding author: gvolia@yandex.ru

\begin{abstract}
Introduction: The need for maintenance and repair of historical buildings is an important and integral part of the preservation of cultural and architectural heritage. Purpose of the study: The study is aimed to find common-ground potential project concepts in the intersection of the new and old in the sacred and the mundane. Methods: The authors perform a theoretical analysis of techniques for restoration of recognized monuments, such as the Hermitage, and ordinary historical objects, and determine a relationship between the concept and the problems of restoration. To demonstrate methods used in restoration, the authors offer specific examples from modern practice in the United States and Russia. Results: The article discusses cases where professionals do not attempt to return buildings to some idealized version from the past, but rather use the restoration process to emphasize the qualities of age, show how they exist in the present, and recognize the built environment as alive, evolving, and constantly changing. The article reflects the work of the authors, including projects from their architectural practice and teaching. Discussion: With regard to the implementation of specific restoration and reconstruction projects, the importance of international interaction is shown in the development of strategies for education and practice in the field of restoration and protection of cultural heritage. The increasing volume of conservation and restoration work puts pressure on developing scientific approaches and methodologies to solve practical problems. At the same time, the restorer must recognize that continuity with the past can exist in the renovation of more mundane and utilitarian structures, which can benefit from less restrictive approaches with regard to the intersection of the old and the new. After all, a trained professional should understand that the approach to each project is unique.
\end{abstract}

\section{Keywords}

Architectural heritage, restoration, adaptation, innovation, historical building structures, Russian and American experience.

\section{Introduction}

International cooperation and development of strategies for education and practice in the field of cultural heritage restoration and conservation require analyzing both the Russian and international experience in the creation and operation of historical sites and structures. Preservation of architectural monuments periodically involves theoretically substantiated conservation and restoration works. Techniques of conservation and restoration applied are fluid and require every restorer to take a creative approach to address issues specific to a given project.

Decay is a fundamental and unavoidable component of the built environment, documenting the passage of time and "stirring our memories and imaginations" (Jurow, 1978). As noted scholar David Lowenthal points out, "buildings are expected to gain through the process of growing old, it is part of the quality we admire in them that they have their history written on their faces" (Lowenthal, 1985). Sociologist Yi-Fu Tuan notes that a sense of age embodied within the architecture of a given community creates a sense of "time depth" and "roots" us to a place, generating a sense of personal attachment (Tuan, 1974). Conservation strategies can both preserve and encourage depth and continuity, recognizing architecture as something alive and evolving.

When determining the appropriate restoration technique of a public facility, of critical importance is the assessment of its historical and architectural value. Facilities deemed to have less historic significance may offer the designer greater license to creatively engage the existing condition and celebrate the intersection of new and old. Reconstruction may be decided upon only in a case when the architectural value of the facility is not high, 
or when a historical structure is in an advanced state of dilapidation requiring immediate intervention to preserve and prolong the life of the monument. Reconstruction is also possible when the monument's utility system needs to be replaced in accordance with the modern requirements of the constantly developing city. The Russian experience of restoration can be considered through the lens of some of the outstanding monuments in St. Petersburg, many of which are under UNESCO protection. To determine the technical condition of the building, it is necessary to have information about its actual structural strength, rigidity, the presence and location of rigid connections, homogeneity, material density, etc. (Lysova and Sharlygina, 1979).

\section{Methods}

The Federal Law "On Objects of Cultural Heritage of the Russian Federation" in Chapter 7 prescribes a number of concepts that define possible measures to be taken within the framework of preserving the object of cultural heritage: conservation (Article 41), repairing of the monument (Article 42), restoration (Article 43), adaptation of the object of cultural heritage for modern use (Article 44), etc. (Federal Law as of 25.06.2002). Restoration and adaptation are assumed to be the most relevant measures at present. The concept of "reconstruction" is not included into the Federal Law, but the Urban Planning Code of the Russian Federation (Clause 14) in a situation where there are few objects of protection on the site, allows some specific activities to be undertaken (Urban Planning Code of the Russian Federation as of 29.12.2004). Besides, sub-clauses 14.1-14.3 provide additional necessary clarifications in the definitions.

The entire historical center of Saint Petersburg and monument complexes related to it have been included in the UNESCO World Heritage List since 1990. In this regard, it seems extremely important to preserve, repurpose and adapt the cultural heritage objects of the city for modern use, as well as to identify and register new monuments of history, culture and architecture.

In recent years, innovative technologies have been actively introduced and new methods have been applied in restoration and adaptation of cultural heritage sites in St. Petersburg to the modern needs of society. Over the past decades, many cultural heritage sites in St. Petersburg have been reconstructed (with varying success), among them the General Staff Building, the Senate Building, the Central Museum of Communications, the DLT, the Passage, the Kamennoostrovsky Theater, and the Kamennoostrovsky Palace. We will also consider examples from abroad, modest in scale but important to provide a frame to evaluate a preservation strategy, such as the work of David Ireland in San Francisco and modifications to historic manufacturing facilities if the same region.

\section{Results}

\subsection{Architectural Heritage Sites of Saint Petersburg} 2.1.1. Kamennoostrovsky Theater, St. Petersburg

Basing on the legislative framework of the Russian Federation in the issue of preservation of architectural monuments, the authors believe that it is possible to correctly combine constructional measures and classical restoration of the monument. The complex of works carried out on the monument of history and culture of the XIX century, namely, the Kamennoostrovsky Theater, which afterwards started to be used as the second stage of the Tovstonogov Bolshoi Drama Theater (BDT), may be regarded as one of the most striking examples of the synthesis of art and engineering.

The Kamennoostrovsky Theater is a unique monument of classical wooden architecture in St. Petersburg, designed by architect S. L. Shustov (1827). The theater is recognized as an object of cultural heritage of the Russian Federation (Figure 1).

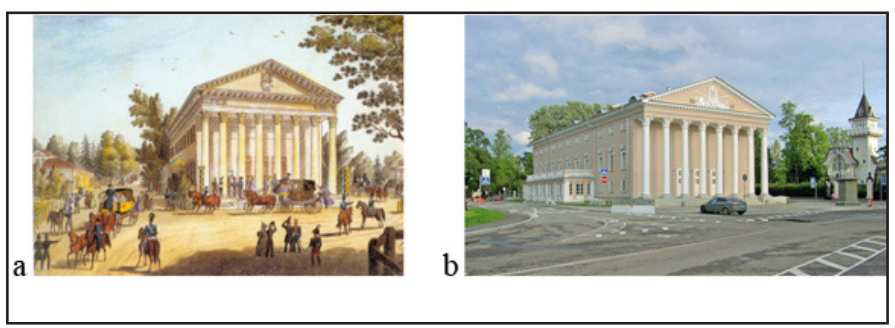

Figure 1. General view of the Kamennoostrovsky Theater: a - a view of the Kamennoostrovsky Theater in the 19th century, a reproduction from the Russian Artistic Journal, Saint Petersburg, 1853, No. 20; b - a 3D model of the modernized Kamennoostrovsky Theater, built by specialists of Georeconstruction company (Dementieva et al., 2014).

In 2007, as assigned by the KGIOP (Government CommitteeforHistoricaland Cultural HeritageManagement), architect V. Burygin developed the concept of theater adaptation, with the construction of an underground garage under the building and the area around it. The architect envisioned the restoration of the wooden building without disassembling it, recreating the historic interiors. Based on this concept, the adaptation of the Kamennoostrovsky Theater was developed and implemented. The project was awarded the gold medal "For outstanding achievements in the field of heritage protection in Europe" at the international exhibition for the protection of monuments "Denkmal" held in Leipzig (Germany) in 2010 under the auspices of UNESCO. The theater was adapted for year-round use and retrofitted with technologically advanced theater equipment while maintaining and preserving the authenticity of the monument. This was made possible by implementing stateof-the-art techniques in the fields of restoration engineering and geotechnical engineering (Handel, 2013).

A unique feature of this project was the development of the underground space in complex engineering and geological conditions of St. Petersburg, with weak clay soils taken into account. St. Petersburg specialists in geotechnical engineering had to develop their structural assessment programs (based on research and data compiled over the course of twenty years), which enabled them to solve complicated foundation conditions. The engineers created a viscoplastic model of the soil simulating the behavior features of water-saturated clay soils. The architects did their best to follow the principle of avoiding any possible harm to the monument when developing the underground space 
under the Kamennoostrovsky Theater, and, accordingly, selected a proper design solution. Based on the research performed, special requirements were developed for the design of deep pits near architectural monuments: analysis of underground structures in urban development had to be carried out for both the project structure itself and for the surrounding housing development. An underpinning was carried out by piling of the historical structures: the historical basement was encircled with a reinforced concrete binding belt, and bored piles were placed along its sides. The load of the building was then transferred onto them using metal beams placed in the windows under the binding belt. The historic wooden piles of the theater ended up between the new underpinning piles. The design of the land cofferdam ensured the preservation of the natural level of groundwater. Meticulous monitoring during the entire period of construction work made it possible to avoid any dynamic effects that exceeded the permissible level of vibration acceleration $\left(0.15 \mathrm{~m} / \mathrm{s}^{2}\right)$ (Figure 2) (Dementieva et al., 2014).

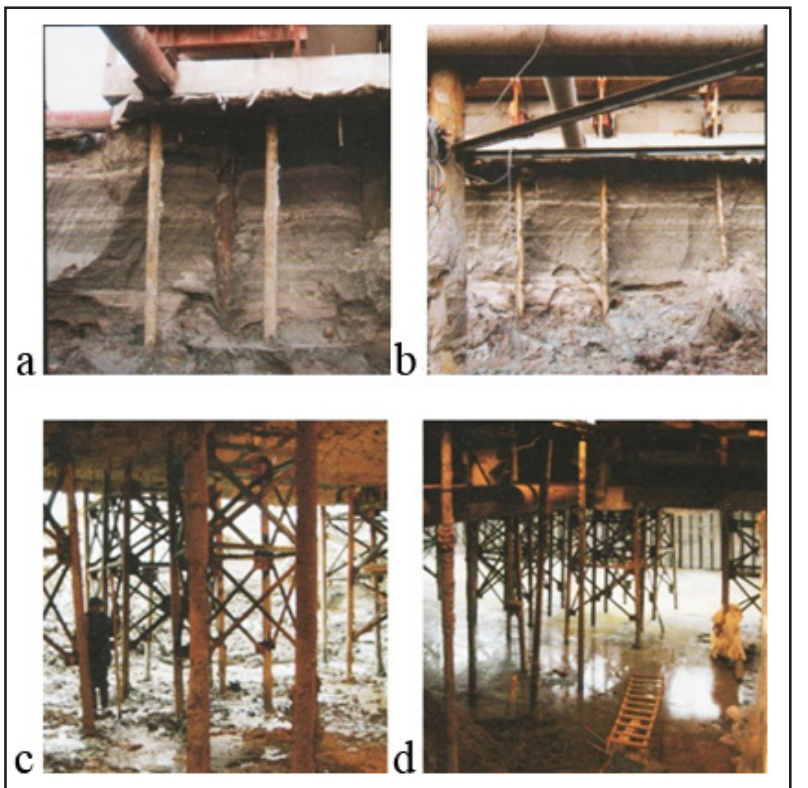

Figure 2. Work on the construction of the underground space under the theater: $a, b-$ excavation of the underground space;

$c, d$ - historical wooden piles between new underpinning piles. Photos made by employees of Georeconstruction company, scan copies from the book "About the

Kamennoostrovsky Theater" (Dementieva et al., 2014).

2.1.2. Museum complex of the State Hermitage Museum, St. Petersburg

During the preparation for the $250^{\text {th }}$ Anniversary of the Hermitage Museum (in 2014), there was a large-scale survey of the Hermitage in the broadest sense: as an architectural complex, as the world and national Museum, as a keeper of the heritage of times and antiquities, as a collector of new and unique exhibits, as an organizer of exhibitions at the highest international level. Restoration and reconstruction of the State Hermitage Museum complex in the Eastern wing of the General Staff Building (the project by N. I. Yavein's Studio 44, 2002-2010) is a unique example of adapting a historical monument to the modern needs of society (Figure 3 ).

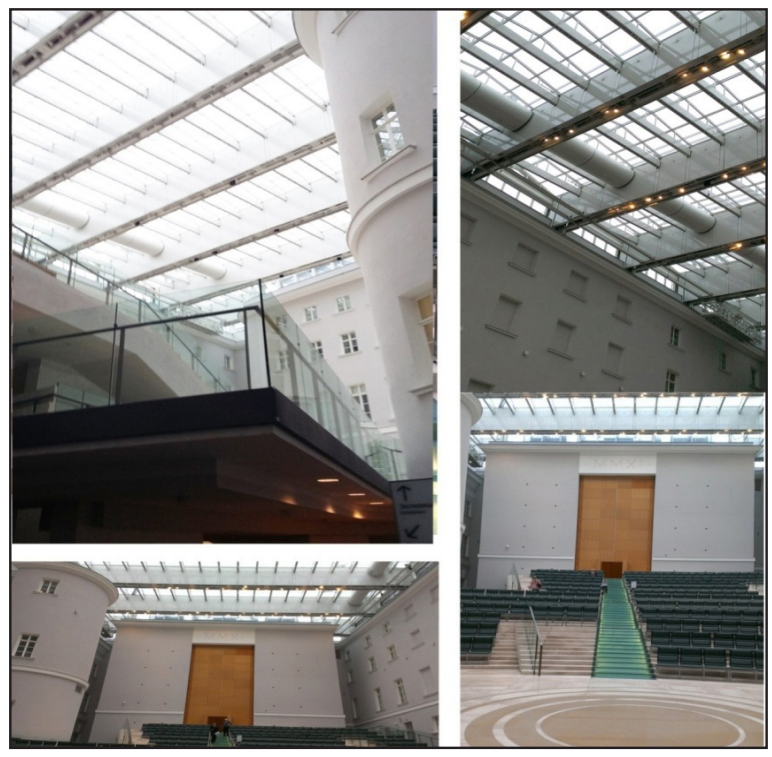

Figure 3. Interiors of the General Staff Building. Photos by the authors (Golovina S. G., 2018).

With the direct participation of foreign experts such as Dutch architect Rem Koolhaas and architectural design studio AMO, the following areas were restored: the attic premises of the Winter Palace, the premises of the Small Hermitage, the new utility rooms equipped with the newest engineering systems for reception and storage of unique museum exhibits, the underground passage between the buildings of the complex (Farahat and Osman, 2018). This was in immediate proximity from the Neva River (less than 6 meters). Despite the fact that the result of the bulk of the work is hidden from view, all activities that were undertaken in both the architectural restoration and the engineering works are of great importance for the proper functioning and introduction of modern equipment to the Museum complex. Some of the latest technologies used in the newly renovated premises can already be appreciated by visitors, e.g. backlit information panels on the walls have replaced the usual signs with text (Figure 4).

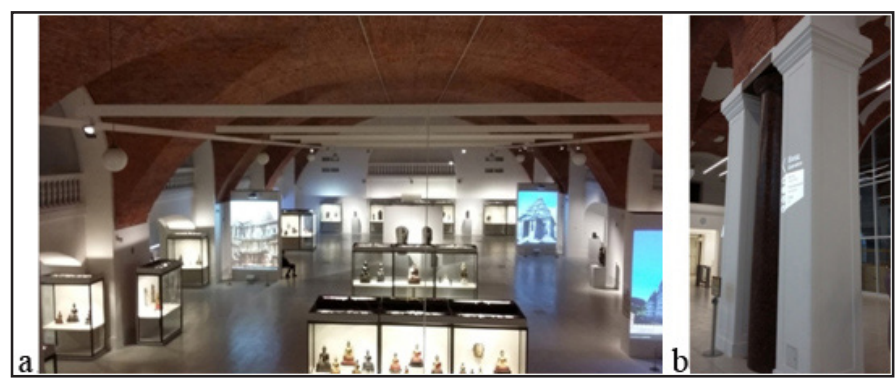

Figure 4. New exhibition spaces in the Small Hermitage: $a-a$ hall with an exposition; $b-$ backlit panels. Photos by the authors (Pastukh O. A., 2016).

Especially noteworthy is the process of reconstruction of the Hermitage's attic space.

Unlike the halls of the Hermitage with their lavish decoration, the attic premises have a very special atmosphere. This is really an unusual space, its architecture is inextricably linked with the architecture of the halls located below (Matsenkov, 2011). The attics of 
the Hermitage can be understood through the transition of material, from wood (before the beginning of the XIX century) to metal (early XIX century). Initially, almost all the buildings of the Hermitage had a wooden rafter system, but after the fire of 1837, the Winter Palace "provided itself" with iron structures. In 1887, the trussed rafters of the Winter Palace were reconstructed. In 1914, a new system of air heating and ventilation was built in the Small, Old and New Hermitage buildings, which some researchers consider to be the world's first air conditioning system created in a museum (Matsenkov, 2011). During the Great Patriotic War, the "front line of defense" of the Hermitage against German invaders was located through the roofs and attics. One of the shells of an anti-aircraft gun of 1939 vintage was found in the sand of the attic above the Tent-Roofed Hall during repair works in 2000. Now, nine separate places show traces of shell damage in the attics of the Winter Palace and the Hermitage - shrapnel wounds on brick walls and deformed iron structures with seams from electric welding. Currently, the attics of the Winter Palace, the Small Hermitage, and the Hermitage Theater contain elevator machinery and air conditioning equipment. In recent years, the attics of the Hermitage have attracted a lot of attention. In 2001, an elevator was installed to get to the attic above the Commandant Entrance of the Winter Palace. The Hermitage attics have an aesthetic component in addition to quite utilitarian functions (the location of the rafter system and the ventilation system). They are beautiful in their own way with their "brick-and-iron" interiors and arouse keen interest of the visitors, opening up another dimension to them (Figure 5).

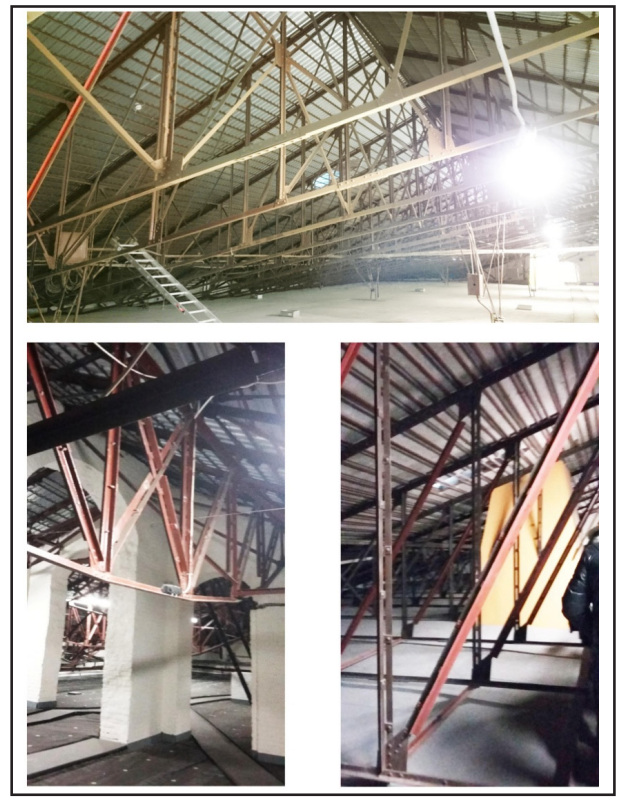

Figure 5. Attic premises of the Hermitage after restoration in 2000. Photos by the authors (Pastukh O. A., a guided tour for the faculty of the Department of Architectural and Engineering Constructions, 2016)

A careful and respectful attitude toward historical structures is the key to the harmonious existence of the past and present. For the preservation of the historical, cultural and urban heritage of St. Petersburg, it is extremely important to implement a radically new approach to the reconstruction of the city center; one which uses "sparing" methods of repair work, is equipped with innovative and advanced technologies and is the most productive use of the limited opportunities for restoration (Pastukh, 2016).

\subsection{Renovation of historical sites in the USA}

\subsubsection{Capp Street, San Francisco, California}

Artist Jim Dine, who works the surfaces of his pastel drawings with sandpaper and gesso to alter but not erase, builds up his drawings and expresses the process of making, the drawing's history, in the finished product (Figure 6). As Dine explains, "overlay and rubbing out come not so much from frustration at what I'm getting as from the confidence that I am going to do it again... and I know I am going to get something richer than if I had left it alone" (Glenn, 1979). The drawing in this case benefits from layering and depth, celebrating and revealing the messiness of the process. We can extend this sensibility to architecture, designers empowered by confidence that restoration will become richer and gain depth through the creative engagement of the existing condition.

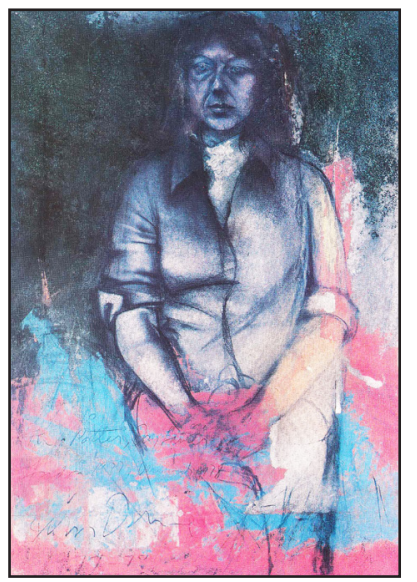

Figure 6. Jim Dine, figure drawing, 1977. Photos by Timothy Gray.

Artist and architect David Ireland brings this same sensibility to architectural restoration, where he treats the restoration of the ordinary with the same reverence and intensity of investigation that an archeologist might bring to a historical dig. In his first built work, 500 Capp Street, the restoration of the artist's own home and studio, Ireland interrogated a historic single-family home located in San Francisco's Mission District as he methodically peeled back the layers of time and emptied years of debris which had accumulated in the house (Figure 7). Rather than trying to restore the home to some idealized version of the past, Ireland's renovation celebrated and revealed the building's history while at the same time making the space functional and whole. "Ireland's goal was not to improve or remodel 500 Capp Street, but, rather, to uncover its history as an artifact molded by human use and the passage of time" (Tsujimoto and Gross, 2003).

Ireland peeled back layers of old wallpaper to reveal plaster and layers of paint, trims removed, floors cleaned 
and oiled. As the contents were emptied, artifacts that caught the artist's eye were removed and cataloged from the stream of debris. These items were then reconfigured and introduced back into the finished space as sculptural installations. Guided by his intuition - the process was arrested at a certain point - Ireland intentionally preserved "stress cracks, water stains and other signs of aging" (Tsujimoto and Gross, 2003) and sealed the walls, ceilings and floors with thick coats of a gloss lacquer. The building was restored to a clean and usable state but celebrated its age and the passage of time by wearing its history on its face.

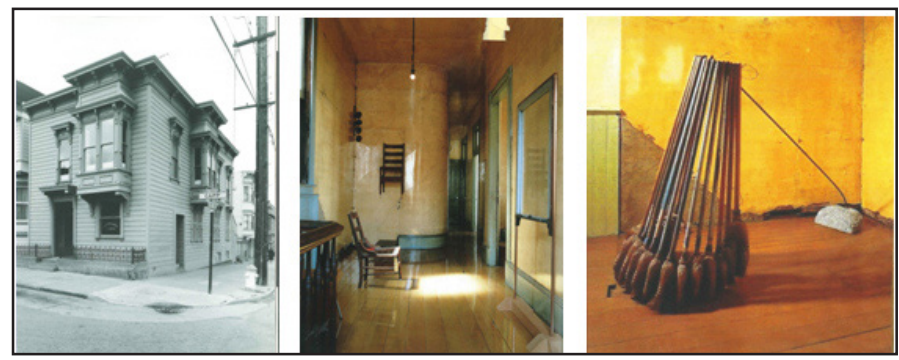

Figure 7. 500 Capp Street, David Ireland. Photos by Timothy Gray.

\subsubsection{Headlands Center for the Arts, Marin,} California

In the Headlands Center for the Arts, located just across the Golden Gate Bridge from San Francisco, Ireland and a team of collaborators embraced the same approach in the conversion of a decommissioned army barracks into a center for artists in residency. Layers of paint are peeled back, walls cleaned and sealed. Furniture systems in the main meeting room, designed by architect Marc Mack, are simultaneously inspired by but distinct from the existing space. The circular geometry of the seating system is set in opposition to the orthogonal regularity of the base building, celebrating and amplifying the unique quality of the base condition through the contrast of material and form (Figure 8).

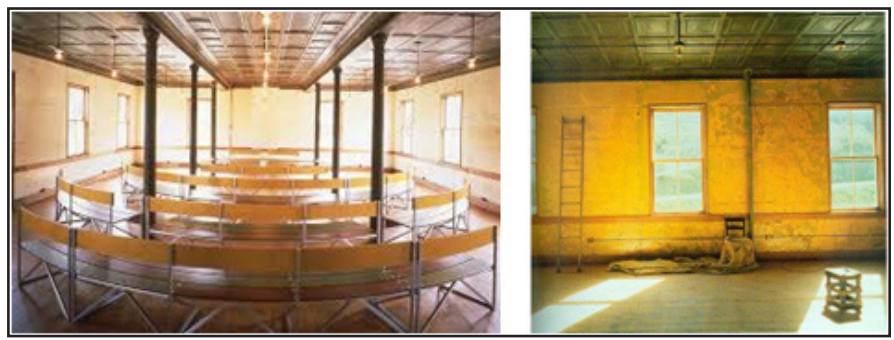

Figure 8. Headlands Center for the Arts, Marin, California, David Ireland, Marc Mack. Photos by Timothy Gray.

\subsubsection{Offices for Vehicle Design, San Francisco}

Inspired by this approach in his own work, both professionally and with students, the author has creatively engaged historic building conditions in similar ways. In the offices for Vehicle Design, San Francisco, a historic post and timber manufacturing facility was converted into offices for the advertising Agency Vehicle Design. As part of the renovation, the three-story unreinforced masonry building had to be brought into compliance with current seismic code. Massive steel moment frames were craned through the roof of the existing building, and the masonry perimeter walls were strapped to the heavy timber frame. The structural reinforcement was not concealed but rather celebrated and allowed to have a strong presence in the finished space (Figure 9).

Existing machinery from the building's past life as a manufacturing facility was removed from the space, leaving voids where the fir flooring had been cut around the machinery mounts. Rather than patching or trying to conceal these imperfections, a cement leveling agent was poured into the voids left by the machinery, making the floor safe and functional but recording and revealing the past use of the building, a layer of time celebrated rather than concealed. New items, such as the conference room at the entry to the space, were constructed using a delicate material palette of aluminum and glass, celebrating the rugged quality of both the new seismic framing and the existing post and timber frame through contrast. The rugged beauty of the timber frame is amplified by the juxtaposition with the material system of glass and aluminum. The inherent beauty of the historic base building condition is celebrated through the contrast of materials and scale. Similar to the Headlands Center for the Arts, custom-designed furniture for the space is inspired by the past but is distinct of the present. Material selections are inspired by the base building but are assembled using clean, crisp lines distinct from the rugged beauty of the base building condition.

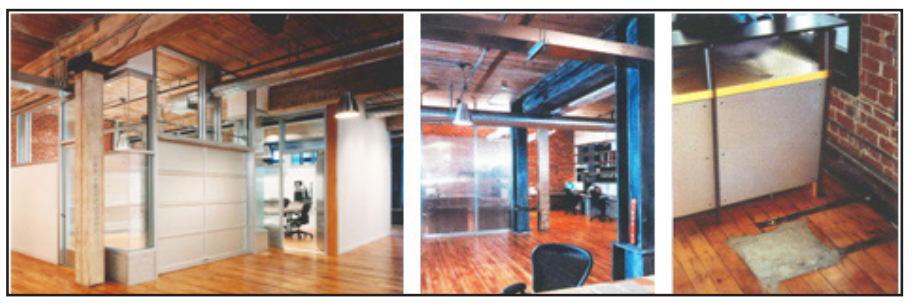

Figure 9. Offices for Vehicle Design, San Francisco, Gray Architecture, reception desk details, conference rooms and a seismic frame. Photos by Timothy Gray.

\section{Discussion}

Preservation of architectural heritage is a topic that not only attracts increased public attention but is also discussed by professionals in a lively, fierce debate. The interests of residents, officials, architects, representatives of business communities, and investors, as well as large construction companies have converged on the question of how and why to preserve monuments (Pastukh et al., 2019). There are a number of pressing problems in the field of monument protection, the answers to which will help to find a consensus in all the variety of professional opinions related to this topic:

1. Why do we need to preserve our heritage? What role should the concept of authenticity play? When is it appropriate to restore lost monuments?

2. Does the government have all the tools to effectively perform the task of protecting the heritage?

3. How can laws in the field of heritage protection and their practical application be evaluated?

4. What is the state of the Russian restoration branch? 
As answers to these questions, it is interesting to hear the opinions of well-known practitioners in the field of preserving the historical urban environment and individual monuments, depending on the specifics of their activities and experience in this field.

\section{Architect Rem Koolhaas: "Conservation"}

It should not be about authenticity or architecture as such, but about preserving visible traces of history so that they would be accessible and understandable unconditionally - not only some good or significant places but also everyday life as well. Designers have a widely spread delusion that it is possible to solve complex cultural and political problems basing on the economy. On the one hand, having embarked on the path of market economy development, Russia very quickly became a victim, especially in large cities, of the same mechanisms of conservation economy as in the rest of the capitalist world. On the other hand, in the Soviet Union, there were many cases of involuntary preservation, when, for example, parts of cities or even regions were either dropped from the field of Soviet planning or frozen by some political reasons. Something similar can be observed today. After the collapse of the USSR, Russia lost much of its coherence. Many airports were closed in small and medium-sized cities. The lack of infrastructure hinders the processes that are associated with the interests generated by the market economy, contributing to the preservation of not only Soviet but even pre-Soviet realities.

\section{Architect Timothy Gray:}

Having practiced for many years in San Francisco, a city subject to extensive codes and ordinances governing the preservation of the city's historic fabric, I can tell you that building owners were typically very reluctant to own or purchase properties listed on the historic register due to the strict limitations and oversight on development. Abundant regulation can limit the economic potential of a given property as well as the potential for creative design solutions. Some of the best and most creative work emerges from the intersection of the new and the old in buildings that embody richness and history but are not deemed historically significant.

Architect Nikita Yavein: "It is almost impossible to recreate monuments":

The process that I observe is not progressing, but is very ragged, jerky, with different speeds, and periodically there are tides of aggressive unprofessionalism. Today, the pendulum swung very far in the defensive direction. On the one hand, the legislation is being tightened. On the other hand, in practice, there is still a very strong wave of aggression against a number of monuments. The legislation is more or less formed. Now more and more investors are working with monuments, who do not want to reckon with the laws. Sometimes there are very strange ideas, for example, a project for UNESCO, where the area of the St. Petersburg security zone is proposed to be 300 square kilometers, which is more than all the security zones in Europe combined. In fact, we have to deal with the remnants of legislation. For example, the law excluded the concept of "reconstruction" and introduced the concept of "adaptation", which is fundamentally inconsistent with the Urban Planning Code. That is, the law is still somewhat detached from reality. In world architectural practice, there is a concept of "special technical condition", when each unique object actually creates its own legislation. The special technical condition is approved accordingly and then acts as a normative act. A historical building and its modern contents are usually absolutely incomparable in value. With this approach, you need to follow the rules of the game very clearly, separating the new from the old, without using any styling. This interpretation of the Venice Charter in 90 cases out of 100 turns out to be parasitic on the old one. Although the possibilities of such a contrast are more often used by Western masters.

\section{Conclusions}

With regard to the implementation of specific restoration and reconstruction projects, the importance of international interaction was shown in the development of strategies for education and practice in the field of restoration and protection of cultural heritage. The increasing volume of conservation and restoration work puts pressure on developing scientific approaches and methodologies to solve practical problems. Consequently, engineering conservation of architectural monuments requires close attention and collaboration of various specialists, primarily architects, restorers, engineers, and archaeologists.

Preservation of historical and cultural monuments is the main task of engineering conservation and restoration. As the analysis of the Russian experience in the field of restoration and reconstruction shows, along with outstanding examples of engineering and architectural thought, there are, to put it mildly, some unsuccessful ones (Pastukh et al., 2018). Each monument possesses individual features that are intrinsic to it, and therefore they have a special value. This is why it is unacceptable to destroy these individual features during restoration. All work should be mechanized as much as possible. This will increase productivity and reduce costs. Methods of production should be constantly improved and thus reduce the labor intensity.

A lot has been done in Russia to preserve the cultural heritage of the past, including monuments of architecture, culture and history. The possibilities of modern construction equipment are practically unlimited. Currently, it is possible to straighten, restore, preserve, lift, move, and save any monument, even in an emergency state, without changing its appearance. Architectural monuments themselves are often the creations of great artists who have invested their skills in them. This means that the restorer renovating the monument does not have the right to change the master's plan and, most importantly, should not miss when restoring what was accurately determined by the remaining traces. At the same time, the restorer must recognize that continuity with the past can exist in the renovation of more mundane and utilitarian structures, which can benefit from less restrictive approaches with regard to the intersections of the old and the new. After all, a trained professional should understand that the approach to each project is unique. 


\section{References}

Dementieva, V. A., Shashkin, A. G., Rakhmanov, V. S. and Burygin, V. L. (2014). Kamennoostrovsky theater. Synthesis of restoration and geotechnical engineering achievements. Saint Petersburg: Publishing House of the Georeconstruction Institute, $272 \mathrm{p}$.

Farahat, B. I. and Osman, K. A. (2018). Toward a new vision to design a museum in historical places. HBRC Journal, 14 (1), pp. 66-78. DOI: 10.1016/j.hbrcj.2016.01.004.

Federal law of 25.06.2002 N 73-FZ (ed. of 30.12.2015) "On objects of cultural heritage (monuments of history and culture) of the peoples of the Russian Federation" (with ed. and extra, Intro. effective from 01.01.2016), Chapter VII (accessed on: 04.02.2020).

Glenn, C. (1979). Jim Dine Drawings. New York: Harry N. Abrams, 223 p.

Handel, E. M. (2013). Engineering work in the restoration of architectural monuments. Moscow: Arkhitektura-S, 208 p.

Jurow, A. (1978). Evocative decay and the maintenance of memory MSc Thesis in Architecture. Berkeley: University of California, Berkeley.

Lowenthal, D. (1985). The past is a foreign country. Cambridge: Cambridge University Press, 489 p.

Lysova, A. I. and Sharlygina, K. A. (1979). Reconstruction of buildings. Leningrad: Stroyizdat, 304 p.

Matsenkov, S. A. (2011). Attics of the Hermitage. Saint Petersburg: Publishing House of the State Hermitage Museum, 112 p.

Pastukh, O. A. (2016). Innovations and traditions in modern restoration on the example of objects of cultural heritage of St. Petersburg. In: Architecture - Construction - Transport: Proceedings of the 72nd Scientific Conference of professors, teachers, researchers, engineers and postgraduates of the university, October 5-7, 2016. In three parts. Part 1. Saint Petersburg: Saint Petersburg State University of Architecture and Civil Engineering, pp. 189-195.

Pastukh, O., Elistratov, V., Golovina, S. and Elistratov, N. (2019). Renovation of the block in Madrid in accordance with criteria of Isover MultiComfort House. MATEC E3S Web of Conferences, 91, 02005. DOI: 10.1051/e3sconf/20199102005.

Pastukh, O., Vaitens, A. and Golovina, S. (2018). Construction of atrium in the Tula Kremlin: history, background and opportunities. MATEC Web of Conferences, 193, 04012. DOI: 10.1051/matecconf/201819304012.

Tsujimoto, K. and Gross, J. (2003). The art of David Ireland: The way things are. Berkeley: University of California Press, 244 p. Tuan, Y.-F. (1974). Topophilia: a study of environmental perceptions, attitudes and values. Englewood Cliffs: Prentice Hall, 260 p. Urban Planning Code of the Russian Federation of 29.12.2004 N 190-FZ (as amended on 30.12.2015) (revision effective from 10.01.2016), capter 14 of the Federal law of 28.11.2011 N 337-FZ (accessed on: 06.02.2020). 


\title{
ВОССТАНОВЛЕННЫЕ СЛОИ: РЕКОНСТРУКЦИЯ ИСТОРИЧЕСКИХ ОБЪЕКТОВ И ВОССТАНОВЛЕНИЕ АРХИТЕКТУРНОГО НАСЛЕДИЯ: ОПЫТ СОЕДИНЕННЫХ ШТАТОВ АМЕРИКИ И РОССИИ (НА ПРИМЕРЕ САНКТ-ПЕТЕРБУРГА)
}

\author{
Ольга Александровна Пастух ${ }^{1 *}$, Тимоти Грей${ }^{2}$, Светлана Геннадьевна Головина ${ }^{1}$ \\ ${ }^{1}$ Санкт-Петербургский государственный архитектурно-строительный университет \\ 2-ая Красноармейская ул., 4, Санкт-Петербург, Россия \\ ${ }^{2}$ Государственный университет Балл \\ Манси, Индиана, США \\ *E-mail: gvolia@yandex.ru
}

\begin{abstract}
Аннотация
Необходимость технического обслуживания и ремонта исторических зданий является важной и неотъемлемой частью сохранения культурного и архитектурного наследия. Цель исследования. Найти точки соприкосновения потенциальных проектных концепций на пересечении Нового строительства и наследия прошлого в сакральном и обывательском смысле. Методы. Теоретический анализ методов реставрации как известных памятников, таких как Эрмитаж, так и тривиальных исторических объектов, а также взаимосвязь между архитектурной концепцией и техническими проблемами реставрации здания. Для демонстрации этих методов реставрации авторы приводят конкретные примеры из современной практики в США и России. Результаты. Рассматриваются примеры, которые не пытаются вернуть здания к какойто идеализированной версии из прошлого, а скорее используют процесс реставрации, чтобы подчеркнуть достоинства сохранившегося образца, как он есть, показать, как он есть, и признать созданную историческую среду живой, развивающейся и постоянно меняющейся. В статье отражена работа авторов, в том числе над проектами из собственной архитектурной практики и преподавания. Обсуждение реализации конкретных проектов реставрации и реконструкции показало важность международного сотрудничества в разработке образовательных стратегий и практик в области реставрации и охраны культурного наследия. Растущий объем природоохранных и реставрационных работ оказывает влияние на развитие научных подходов и методик решения практических задач. В то же время реставратор должен признать, что преемственность с прошлым может существовать при реконструкции более обыденных и утилитарных структур, которые могут извлечь пользу из менее ограниченных подходов к взаимодействию прошлого и современности. Ведь квалифицированный специалист должен понимать, что подход к каждому проекту уникален.
\end{abstract}

\section{Ключевые слова}

Архитектурное наследие, реставрация, адаптация, инновации, исторические строительные конструкции, российский и американский опыт. 